\title{
The Impact of Foreign Retail and Wholesale Stores on Traditional Wholesale Stores in Nonthaburi Province, Thailand
}

\author{
Supitcha Cheevapruk, John Walsh* \\ School of Management, Shinawatra University, Thailand \\ *jcwalsh@siu.ac.th
}

\begin{abstract}
The entrance of foreign retail and wholesale businesses in Thailand started some ten years ago and led to the closure of many Thai wholesale stores. The objective of this study is to determine the needs of Thai wholesalers in the Nonthaburi area and to identify suitable strategies for relevant managers to be able to compete with contemporary commercial strategies of the foreign enterprises. A total of 114 of the 120 Thai traditional wholesale stores in Nonthaburi were surveyed by questionnaire and results were analyzed by statistical means. It was found that low price strategy, location of store and full cycle service strategies were the principal approaches employed by the managers of the foreign wholesale and retail stores. Tesco Lotus was the foreign venture with the greatest impact on the Thai environment. With respect to managerial approach, it was found that Thai traditional wholesale stores should try to build stronger relationships with customers and regularly search for new markets. Employee performance should also be taken into consideration to some extent. Other issues of importance included the presentation of the store and visual merchandising, as well as transparency in management systems and the need for well-organized financial and accounting systems and their proper control.
\end{abstract}

Keywords: Wholesale trade, wholesale markets, Thailand, retail

\section{Introduction}

Thailand's retail sector has become more thoroughly globalised in recent years, particularly as a result of the 1997 financial crisis and the opportunities that provided for foreign investors to insert themselves into both the retail and wholesale sectors (Mutebi, 2007). Since the legal structure does not permit foreign operators total freedom in these sectors, they continue to work in partnership with local enterprises (See Table 1).

Table 2: Ownership of Foreign Wholesale Chains; source: authors' research

\begin{tabular}{lll}
\hline Company & Thai Owner & Overseas Owner \\
\hline Lotus & CP & Tesco (UK) \\
Macro & CP & SHV Holding (Netherlands) \\
Big C & Central Retail & Casino (France) \\
Carrefour & Central Retail & Carrefour (France) (sold and rebranded as Big C stores) \\
Tops & Central Retail & (Netherlands) \\
Food Lion & The Mall & (Belgium) \\
Family Mart & Robinson & Family Mart (Japan) \\
Watson & Central Retail & Watson (Hong Kong) \\
Office Depot & Central Retail & Office Depot (USA) \\
\hline
\end{tabular}

Macro, for example, is a wholesale operator using the cash and carry model and was established in 1988 with capital of 750 million baht. The first branch of Macro was located in Lad Prao in 1989. Macro's vision is to sell products at lower prices than competitors through minimizing the managerial budget, to be the source of material for retail stores, food entrepreneurs and other services businesses and to maintain satisfaction levels by presenting only products of suitable quality. Meanwhile, Carrefour is the number one retailer in France and has been looking to internationalize so as to expand the business beyond national borders. Carrefour is the originator of the hypermarket concept, which combines low cost supermarket with department store. The company started its venture as a partner of Central Retail Cooperation (CRC) and adopted the name CenCa Co. Ltd. It continued to open at least two new branches annually in competition 
primarily with Tesco-Lotus before deciding to sell its chain, which have now become Big C stores, branded as Big C+. Tesco started business in Thailand in 1998 by buying $75 \%$ of the shares of Lotus Supercentres from the CP group. Now it has become the largest and most powerful operator in the Thai multiple retail market. It has been achieving $10 \%$ growth in capacity and sales annually and has introduced a range of different retail concepts (cf. Walsh, 2008). Tesco has a distribution centre at Wangnoi in the province of Ayutthaya, which is valued at 1,300 million baht (US\$43 million) and sorts and distributes some 500,000 items around the country every working day. Tesco now utilizes Thai products in its global supply chains and so helps to provide a significant level of employment in the Thai economy as a whole. Finally, Big C was the first company to provide a retail supercentre in Thailand, which is did at is Chaeng Watthana Road site in Bangkok in 1993. Owners Central Retail Corporation has been trying to expand Big C's market share by targeting middle and upper class consumers, particularly in urban environments. Increasing investment has meant that annual sales of 10 billion baht (US330 million) have yielded disappointing profits. Following the 1997 crisis, Big C was forced to take a foreign partner (Casino Guichard-Perrachon) to raise more capital and subsequently moved to a more down market strategy that has subsequently been reversed to some extent by the purchase of the Carrefour chain (Jitpleecheep, 2011). The presence of these large and modern operators has contributed to the professionalization of Thailand's retail and wholesale industries. These are industries that are quite substantial in size and significant for employment. According to the 2010 Business and Trades Survey conducted by the National Statistical Office (NSO, 2012), there were a total of 1,606,418 business operations within the Kingdom of Thailand, of which 772,701 (or 48.1\%) are in the retail goods and repair of personal and household goods category and a further 75,191 (4.7\% of the total) are in the wholesale and commission trade (excluding motor vehicles and motorcycles). For traditional Thai-owned wholesalers, the competitive environment has been transformed and companies must either learn to compete or else be bankrupted. This research focuses on the response to such changes in a sample of wholesalers in the province of Nonthaburi, which is adjacent to the capital city and province of Bangkok. As a result, many such wholesalers will supply the internationalized and highly modernized retail systems of Bangkok. In what ways, specifically, will existing wholesalers need to update and upgrade their processes and policies so as to be able to compete in this rapidly changing environment?

\section{Literature Review}

Wholesaling has developed considerably in terms of practice and scope in modern business markets (Alderson, 1949). The various services that wholesalers, as intermediaries between producers and retailers, are detailed in table 2 . The nature of wholesalers has been continually refined depending on the specific nature of a particular sector of the retail industry and the nature of the environment and of competition. Wholesalers can, therefore, take the form of (among others) merchant wholesalers, full- or partial-service wholesalers, jobbers, cash and carry wholesalers, specialty and drop shipment wholesalers and the like. For the purpose of this research, all those businesses are defined as wholesalers if they act as intermediaries between producers of goods and the retailers of those goods, which possess some characteristics traditionally associated with wholesalers. According to Thailand's Ministry of Commerce, in announcement 275/2006 on September $29^{\text {th }}, 2006$, the modern wholesale and retail business is defined as those activities involved with the purchasing of consumer daily products with proper purchasing systems, categorization of products and a managerial approach even with respect to franchising. In other words, the government has sought to identify the ways in which a traditional market activity may aspire to being modernized in the way that the government defines and, hence, can be expected to provide incentives for businesses, which follow that requirement. This contrasts with the traditional model of Thai wholesaling, which has the following characteristics:

- Low capital: the traditional trade needs less capital because it is unnecessary for the traditional trade shop to be decorated, has just enough space to keep the entire product in the warehouse. Furthermore, most of the shops have very low human resource cost since most of the shops are run by the owning family or the person who lives in the house and lastly there is no administrative cost and there is no need for the owner to rent or buy modern equipment.

- Location: most of Thailand's traditional trade is located in local areas where retailer and end consumers are located and this reduces the need for marketing.

- Managerial approach: the managerial approach is not complicated; sometimes only one salesperson or the owner alone can run the shop. 
- The relationship with the customers: since most shops are located in local areas where customers are so it keeps the relationship between wholesalers, retailers and end users close to each other.

Table 2: Services Provided to Producers and Retailers Services provided to producers Services provided to retailers

$\begin{array}{ll}\text { Selling } & \text { Wholesalers represent producers as a sales } \\ & \text { representative, perhaps on an exclusive basis and } \\ \text { perhaps not, since the producers themselves do not } \\ \text { find it possible or efficient to search for those } \\ \text { customers themselves. In the case of this study, } \\ \text { most customers would be expected to be located in } \\ \text { the locality and the two parties, producer and } \\ \text { wholesaler, would be likely to share communication } \\ \text { and coordination costs } \\ \text { Since wholesalers are the ones making direct } \\ \text { contact with the customers, they are in a good } \\ \text { position to evaluate future demand from those } \\ \text { customers. Additionally, they can provide feedback } \\ \text { that enables the producer to make desired } \\ \text { improvements in packaging and new product } \\ \text { development. }\end{array}$

Transportation Wholesalers in this case tend to be located close to customers and hence can reduce transportation costs that would otherwise be borne by the producers. Economies of scale and scope effects come into play here.

Storage Wholesalers provide space in the form of storage areas which can be used by the producers for a fee and costs overall are reduced because of efficiencies that the wholesaler, as an expert in the field, can employ.

Finance Wholesalers can improve the cash flow between customers and producers, since the wholesaler can if necessary use own resources to pay upfront where required. Of course, this service represents a cost to the wholesaler that must be met by other stakeholders eventually.

Risk Bearing Since the wholesaler takes delivery of the goods and will store them on own premises at least for some amount of time, then it is the wholesaler who bears the risk of loss or spoilage of items in the interim. This is also a cost, which will need to be met in due course.

Buying

Marketing Information

Source: authors' synthesis of various sources

The wholesalers help and share the transportation cost because when the wholesalers order in large quantity, the transportation cost per unit is reduced.

The wholesalers help the retailers carry the products so the retailers are able to order in small volume, no need to carry the product in warehouse.

To help the retailers not to bear too much risk by order in small quantity and to help them with the financial cash flow.

The wholesalers are taking care of the purchasing activities for the retailers and being the buyer for the retailers and the industrial users because the wholesalers are closely to the retailers so that they know the demand of the products.

To know the marketing information and the demand of the product directly from the local area. 
These characteristics are likely to change with the imposition of more modern commercial practices associated with the introduction of international capital (Shankar, Posri and Srivong, 2010; Coe and Wrigley, 2007). The current research aims to shed some light on how wholesaler firms can change with respect to these changes by means of developing more efficiency and productivity. It is anticipated that the means of improving these business practices will be quite closely related to parts of the marketing mix, which have already been delineated in terms of business strategy, but which can be applied to the particular situation more closely (e.g. Lummus, Duclos and Vokurka, 2003). It has become increasingly evident that the growth of urban areas such as the periphery of Bangkok, where this research project took place, has had the effect of transforming living spaces in cities from being places of production to being places of consumption (Zukin, 1998): as part of the change in lifestyles, complex retail strategies have been designed and integrated to contribute to the individualistic and communal pursuit of cultural capital (Bourdieu, 1984). Retail strategies have been developed over the course of the many centuries during which mostly small-scale retailing has taken place. Much of this strategy has been intuitively and individually; retail strategy as understood in the contemporary business environment developed from the typology of consumer goods that included convenience shopping and specialty goods and went on from there (Bucklin, 1963). The analysis of functional details of retail transactions for purposes of strategy has subsequently been supplemented by knowledge and understanding gained from human psychology and the insights this provided for consumer behavior and for distinction between different types or segments of consumers (Jarratt, 1996). This has enabled marketers to understand and delineate different channels for retailing and wholesaling and the benefits to be obtained from making properly informed decisions with respect to which channels to use and how (e.g. Berman and Thelen, 2004; Reynolds, Ganesh and Luckett, 2002). An additional element feeding into the development of strategy has been the inclusion of the importance of networks of relationships and personal relationships in determining consumption decisions originally introduced by the Uppsala school (cf. Anderson, Håkansson and Johanson, 1994). Putting together these different approaches has led to the creation of a sophisticated marketing mix and segmentation approach at the industrial and firm levels; the different elements of the marketing mix are deployed as appropriate based on the relationships between buyers and sellers in a series of distribution chains (e.g. Evans, Mavondo and Bridson, 2008). This leads to the use of advertising and promotional campaigns that are familiar to the contemporary urban resident and, indeed many others.

\section{Methodology}

This research study employed a quantitative survey approach to examine the managerial practices of wholesale company managers in Nonthaburi. A questionnaire was created, using the Thai language, based on an evaluation of literature relating to management practices. Question areas addressed human resources, marketing and operational practices and were structured according to the Likert scale approach, which facilitates the creation of mean scores for constructs incorporating a variety of different variables in specific management areas. Selection of potential respondents was undertaken according to geographical and operational criteria: eligible companies present in Nonthaburi and involved in some form of wholesaling activities. To try to ensure that potential respondents adhered to the traditional method, respondents were only included if they had been in a managerial position for not less than five years and the company involved has been profitable or at least in operation for five years or more. Once suitable respondents had been identified, the questionnaire was sent to each directly and subsequently collected, checked and analyzed via computer software. As a result of the methodology employed, there are clear limitations in terms of the time and space in which the data collection took place and the possibility of non-response bias, which is difficult to assess because no comprehensive list of wholesalers in the region exists. From an epistemological perspective, a logical positivist paradigm is adopted in which hypotheses are formulated as possible relationships between variables and then converted into null format. Statistical means are employed to determine whether the supposition of non-relationship can be disproved, hence leading to the rejection of the null hypothesis and, hence, the acceptance of the positive hypothesis of a relationship. That relationship is then interpreted.

\section{Results}

Profile: A total of 144 complete responses were obtained, of which 112 were single store businesses and the remaining two represented multiple store businesses. The wholesalers may be divided into six principal 
areas of business activity: 20 were in food and beverages; 18 were in medicines; 17 were involved in toys and souvenirs; 20 were in materials and equipment; 19 were involved in leather and clothing and the remaining 20 were in plastics and others. In terms of staff, 93 businesses had 10 or fewer, 13 had 10-20 and 8 had more than 20 staff members. Only 6 had been in business more than 20 years and another 7 from 15-20 years, with the remainder in business for less time. After foreign wholesalers established their operations in Nonthaburi, $97 \%$ of respondents reported that their profits had declined. Of these, $20 \%$ had seen sales volume decline by less than $10 \%, 72 \%$ had seen sales volume decline from $10-20 \%$ and the remainder had seen sales volumes decline more than $20 \%$. They were mostly involved, therefore, in searching for ways to fight back and increase their numbers of customers, as described below.

Managerial Strategy: Respondents were questioned as to the importance of various managerial techniques that they might have used in attempting to retain existing customers and gain new ones. These were divided into various categories and overall means computed, as follows:

Table 3: Relative Importance of Management Constructs; source: original research $(n=144)$

\begin{tabular}{lll}
\hline Technique & Mean (1-5 = high) & SD \\
\hline Managerial Approach & 3.60 & 0.53 \\
Consumer Management & 3.57 & 0.60 \\
People Management & 3.38 & 0.58 \\
Merchandise Management & 3,79 & 0.62 \\
Financial Management & 3.65 & 0.73 \\
\hline
\end{tabular}

It should be a matter of concern that issues of people and customer management are rated lowest by these Thai wholesalers, when it is likely that these techniques will be more efficacious in retaining customers in the long term. Such techniques are also likely to mark the distinction between local and international businesses. Each of the constructs enumerated above was composed of a variety of different variables, which were also evaluated, as seen below.

Table 4: Relative Importance of Managerial Style Variables; source: original research ( $\mathrm{n}=144$ )

\begin{tabular}{|c|c|c|c|c|c|}
\hline Variable & Mean & SD & Variable & Mean & SD \\
\hline Consumer Management & 3.57 & 0.60 & People Management & 3.38 & $\begin{array}{l}0.5 \\
8\end{array}$ \\
\hline $\begin{array}{l}\text { To build a good relationship with the } \\
\text { customer }\end{array}$ & 4.39 & 0.79 & $\begin{array}{l}\text { Clear demarcation between duties } \\
\text { and responsibilities }\end{array}$ & 3.76 & $\begin{array}{l}1.0 \\
0\end{array}$ \\
\hline Often seek new customers & 4.15 & 0.87 & Having partnership policy & 2.87 & $\begin{array}{l}1.1 \\
8\end{array}$ \\
\hline Give catalogue of goods to customers & 3.31 & 1.15 & Establish activities to foster unity & 3.32 & $\begin{array}{l}1.0 \\
3\end{array}$ \\
\hline Increase sales channels & 3.68 & 0.99 & $\begin{array}{l}\text { Pay attention to family members of } \\
\text { staff }\end{array}$ & 3.20 & $\begin{array}{l}1.0 \\
0\end{array}$ \\
\hline $\begin{array}{l}\text { Give information and guidance about } \\
\text { goods }\end{array}$ & 3.82 & 0.93 & $\begin{array}{l}\text { Punishing officers who make } \\
\text { mistakes }\end{array}$ & 4.00 & $\begin{array}{l}0.9 \\
3\end{array}$ \\
\hline Sales promotion & 3.39 & 1.11 & $\begin{array}{l}\text { Rewarding officers who perform } \\
\text { well }\end{array}$ & 3.91 & $\begin{array}{l}0.9 \\
1\end{array}$ \\
\hline Credit prolongation & 3.24 & 1.06 & $\begin{array}{l}\text { Using a time recorder to control } \\
\text { working hours }\end{array}$ & 3.34 & $\begin{array}{l}1.1 \\
1\end{array}$ \\
\hline Deliver goods on time & 3.85 & 1.14 & $\begin{array}{l}\text { Sending cards or gifts to officers on } \\
\text { important days }\end{array}$ & 3.06 & $\begin{array}{l}1.0 \\
6\end{array}$ \\
\hline Faulty goods exchange service & 3.31 & 1.13 & $\begin{array}{l}\text { Receiving officers recommended by } \\
\text { reliable people }\end{array}$ & 3.33 & $\begin{array}{l}0.9 \\
9\end{array}$ \\
\hline $\begin{array}{l}\text { Provide chance to customers to } \\
\text { exchange goods }\end{array}$ & 3.18 & 1.14 & $\begin{array}{l}\text { Having rotational function policy } \\
\text { for officers }\end{array}$ & 3.03 & $\begin{array}{l}1.1 \\
9\end{array}$ \\
\hline $\begin{array}{l}\text { Have database to provide faster and } \\
\text { more convenient services }\end{array}$ & 3.46 & 1,09 & Financial Management & 3.65 & $\begin{array}{l}0.7 \\
3\end{array}$ \\
\hline Sending cards to customers on special & 3.36 & 1.06 & Use computer system to assist & 3.55 & 1.1 \\
\hline
\end{tabular}




\begin{tabular}{|c|c|c|c|c|c|}
\hline occasions & & & financial work & & 6 \\
\hline $\begin{array}{l}\text { Sending gifts to customers on special } \\
\text { occasions }\end{array}$ & 3.32 & 1.07 & $\begin{array}{lrrr}\text { Use computer } & \text { system } & \text { in } \\
\text { accountancy work }\end{array}$ & 3.51 & $\begin{array}{l}1.1 \\
6\end{array}$ \\
\hline Increase ways of payment & 3.55 & 1.02 & Credit accounting for investment & 3.48 & $\begin{array}{l}1.1 \\
5\end{array}$ \\
\hline Merchandise Management & 3.79 & 0.62 & Pay loans on time & 3.68 & $\begin{array}{l}1.0 \\
7\end{array}$ \\
\hline $\begin{array}{l}\text { There is a certain purchasing (refill) } \\
\text { point }\end{array}$ & 3.79 & 0.97 & Have active controls & 3.88 & $\begin{array}{l}1.0 \\
5\end{array}$ \\
\hline Receiving orders from many suppliers & 3.87 & 0.95 & Have a cash keeping machine & 3.67 & $\begin{array}{l}1.1 \\
3\end{array}$ \\
\hline $\begin{array}{l}\text { Create a good relationship with } \\
\text { supplier }\end{array}$ & 3.86 & 0.95 & Pay taxes on time & 3.82 & $\begin{array}{l}1.0 \\
1\end{array}$ \\
\hline Always count the stock & 3.90 & 0.95 & Have efficient debt-collecting policy & 3.86 & $\begin{array}{l}1.0 \\
6\end{array}$ \\
\hline $\begin{array}{l}\text { Having a policy for dead and broken } \\
\text { stock }\end{array}$ & 3.71 & 0.96 & $\begin{array}{l}\text { Change hiring system from monthly } \\
\text { to daily basis }\end{array}$ & 3.07 & $\begin{array}{l}1.2 \\
4\end{array}$ \\
\hline $\begin{array}{l}\text { Having good and safe places for } \\
\text { storage of goods }\end{array}$ & 3.78 & 1.03 & $\begin{array}{l}\text { Have good financial } \\
\text { accountancy policies }\end{array}$ & 3.98 & $\begin{array}{l}1.0 \\
1\end{array}$ \\
\hline Have a guarantee for goods & 3.56 & 1.16 & & & \\
\hline Arrange goods in groups & 4.12 & 0.89 & & & \\
\hline Have good and attractive decorations & 3.99 & 0.89 & & & \\
\hline $\begin{array}{l}\text { Make sure packaging is strong and } \\
\text { attractive }\end{array}$ & 3.99 & 0.89 & & & \\
\hline $\begin{array}{l}\text { Mark up prices using flexible pricing } \\
\text { policy }\end{array}$ & 3.67 & 0.96 & & & \\
\hline Seek partners for trading & 3.53 & 1.11 & & & \\
\hline
\end{tabular}

Short-term transactional issues appear to be more important than the building blocks of long-term relationships, although some aspects of these are also considered relatively important. The importance of building good long-term relationships with customers is considered to be important but the means of building those relationships is stated primarily in pragmatic and practical terms. This rather suggests that relationships are low-trust in nature, in that the important factors are physical rather than emotional or cognitive in nature. In terms of strategy formulation, subsequent analysis determined that customers were primarily interested in discounts rather than any other form of marketing, although a proportion did also request prolongation of credit terms. It has been concluded that market development of customers - that is, attempting to educate customers as to the potential benefits receivable from other forms of service and product provision - should be part of wholesalers' overall strategy, with the long-term view of developing knowledgeable business partners to supplement the short-term view of reducing costs where possible.

Recommendations: The purpose of this study was to find means by which traditional style Thai wholesalers could adapt their practices to compete better in a competitive environment in which international investment has become increasingly important and influential. It is necessary, therefore, to provide some recommendations as to how those wholesalers should improve their practices, which is the purpose of this section. The most important issue would seem to relate to forming and reproducing good customer relationships. While not ignoring the practical issues that have been used to date to sustain good quality, it is necessary to increase personal relationships through a form of customer relationship management. New customers might be attracted initially by pricing strategy or some form of promotional activity but once they have been attracted, wholesalers should use more advanced and personalized means of deepening relationships. This includes such measures as integrating supply and demand processes so that, for example, the wholesaler can move towards a lean supply approach by co-ordinating better receiving stock from producers and supplying it to retailers, conducting suitable research on retailers so as to be able to suggest additional, complementary products, which might be attractive to them and so forth. At the same time, the wholesalers must become aware of the terms and conditions provided by newcomers to the market and take advantage of any form of dissatisfaction while building capacity to offer new services that are proving to be 
successful elsewhere. To a limited extent, it will be possible to draw upon a sense of loyalty (or just inertia) among existing customers and some economic nationalism to retain some relationships. Government regulations might help with this but, ultimately, such a response will be shown to rely on a market distortion, which is not sustainable in the long run. Finally, it will be important to professionalize business operations for those companies that have so far failed to do this. At the very least, this will require computerization of systems such that inventory levels are automatically kept up-to-date and both retailers and producers can be communicated with regularly and without the need for too much human involvement. Although labor costs have been traditionally very low in Thailand, this has contributed to low levels of labor productivity in the country, which are not matched in other countries, where businesses have sought to sue technology and superior management competencies to drive down operating costs and, therefore, appear more attractive to potential customers. At the same time and at least as important, such techniques tie customers to wholesalers, reducing transaction costs within that relationship and, hence, creating an entry barrier that might deter potential competitors. Finally and in the same vein, knowledge about good practice can be accumulated and distributed via the Thailand Wholesalers' Association and related organizations. Attempting to improve standards within the industry as a whole is not only a good idea from an economic perspective but is also advantageous for existing participants because high standards can be used as a means of deterring new entrants.

\section{Conclusion}

Increasing globalization of all industry sectors in Thailand as elsewhere has meant that traditional business practices are becoming rapidly outmoded and must either adapt to the enhanced level of competitiveness or else be bankrupted. The wholesale industry in Nonthaburi province in Thailand, as described in this paper, is no different to the general pattern. In some cases, this can simply mean doing the same things, only better, while in other cases it requires a radical transformation of business processes and policies. In this case, the competitive environment has been affected most profoundly by the entry of large, powerful retail chains that have the capability to open large chains of operations across the country, thereby taking advantage of economies of scope and scale and almost at once destroying the competitive advantages of many incumbents. One of the principal implications of this has been the change of scale employed. Large chains operate not just at the national scale but integrate national and international forces of production and consumption. A company such as Tesco-Lotus, for example, unites local farmers in provincial Thailand with international consumers across the world. Small scale operators are unlikely to be able even to begin to replicate this kind of activity at their current level of operation and will not be able to grow to the level required. It is, on the other hand, possible to conceive of a network of business operations, which pool their resources and competencies so as to gain the ability to act internationally. However, there is no evidence that this is about to happen or even that wholesalers within Thailand have the intention of uniting with their competitors to try to compete on a different spatial scale. One way in which small-scale wholesalers could still operate effectively is through the intermediating use of technology, the annihilation of space and time that is through the agency of the internet. Thai wholesalers could use technology to create applications that would enable them to compete effectively within niche sectors and activities. It is necessary, in other words, to remove the scale of operation from consideration of activities and compete in areas where no other rival can intervene. It seems unlikely that this will be a sustainable strategy for many companies but it might offer a period of grace during which current wholesalers can seek to make the transition to other types of activities. It almost goes without saying that there is a need for much more research to track existing changes from a longitudinal perspective and also to extend the geographical and industrial basis so as to determine the extent to which current results may be reasonably generalized.

\section{References}

Alderson, W. (1949). Scope and Place of Wholesaling in the United States. Journal of Marketing, 14(2), 145-55. Anderson, J. C., Håkan, H. \& Jan, J. (1994). Dyadic Business Relationships within a Business Network Context. Journal of Marketing, 58(4), 1-15.

Berman, B. \& Thelen, S. (2004). A Guide to Developing and Managing a Well-Integrated, Multi-Channel Retail Strategy. International Journal of Retail and Distribution Management, 32(3), 147-56. 
Bourdieu, P. (1984). Distinction: A Social Critique of the Judgment of Taste (Cambridge MA: Harvard University Press, 1984), translated by Richard Nice.

Bucklin, L. P. (1963). Retail Strategy and the Classification of Consumer Goods. Journal of Marketing, 27(1), 50-5.

Coe, N. \& Wrigley, N. (2007). Host Economy Impacts of Transnational Retail: The Research Agenda. Journal of Economic Geography, 7(4), 341-71.

Evans, J., Mavondo, F. T. \& Bridson, K. (2008). Psychic Distance: Antecedents, Retail Strategy Implications, and Performance Outcomes. Journal of International Marketing, 16(2), 32-63.

Jarratt, D. G. (1996). Shopper Taxonomy for Retail Strategy Development. The International Review of Retail, Distribution and Consumer Research, 6(2), 196-215.

Jitpleecheep, P. (2011). Big C Begins Overhaul, Bangkok Post (January 6 $6^{\text {th }}, 2011$ ), available at: http://www.bangkokpost.com/business/economics/214655/big-c-begins-overhaul.

Lummus, R. R., Duclos, L. K. \& Vokurka, R. J. (2003). The Impact of Marketing Initiatives on the Supply Chain. Supply Chain Management: an International Journal, 8(4), 317-23.

Mutebi, A. M. (2007). Regulatory Responses to Large-Format Transnational Retail in Southeast Asian Cities. Urban Studies, 44(2), 357-79.

National Statistical Office of Thailand (NSO). (2012). Executive Summary, available at: http://web.nso.go.th/en/survey/data-survey/550917-bts.pdf.

Reynolds, K. E., Ganesh, J. \& Luckett, M. (2002). Traditional Malls vs. Factory Outlets: Comparing Shopper Typologies and Implications for Retail Strategy. Journal of Business Research, 55(9), 687-96.

Shankar, B., Posri, W. \& Srivong, T. (2010). A Case Study of a Contract Farming Chain Involving Supermarkets and Smallholders in Thailand. Canadian Journal of Development Studies, 31(1-2), 137-53.

Walsh, J. (2008). Tesco Lotus Thailand: Managing Stakeholders in a Hostile Environment in B.S. Sahay, Tojo Thatchenkery and G.D. Sardana, Handbook on Management Cases (New Delhi: Allied Publishers Pvt. Ltd., 2008), 447-51.

Zukin, S. (1998). Urban Lifestyles: Diversity and Standardization in Spaces of Consumption. Urban Studies, 35(5-6), 825-39. 